\title{
EFFECT OF SODIUM VALPROATE AND DOCOSAHEXAENOIC ACID ON INFLAMMATION IN RATS
}

\author{
SUSHIL KIRAN KUNDER, BAIRY KL*, AVINASH A
}

Department of Pharmacology, Kasturba Medical College, Manipal University, Manipal, Karnataka, India. Email: kl.bairy@manipal.edu

Received: 17 September 2016, Revised and Accepted: 29 September 2016

\section{ABSTRACT}

Objective: To evaluate the anti-inflammatory activity of sodium valproate and docosahexaenoic acid (DHA) supplementation using various experimental models in albino Wistar rats.

Method: A total of 48 adult Wistar albino male rats were divided into 8 groups of 6 rats each. Group I was control (distilled water 1 ml/kg), Group II received intraperitoneal (i.p.) injection of indomethacin (10 mg/kg), Groups III-V were injected (i.p.) with sodium valproate 100 , 200 , and $400 \mathrm{mg} / \mathrm{kg}$ water, and Groups VI-VIII were given sodium valproate 100, 200, and $400 \mathrm{mg} / \mathrm{kg}$ plus DHA $300 \mathrm{mg} / \mathrm{kg}$ (i.p.), respectively. Anti-inflammatory activity was assessed using carrageenan induced paw edema and the cotton pellet granuloma models.

Results: We found that higher doses of sodium valproate $(400 \mathrm{mg} / \mathrm{kg}$ ) used either alone or with a combination of DHA (300 mg/kg) showed a significant anti-inflammatory activity when compared to control in both the models of inflammation.

Conclusion: Combination of sodium valproate along DHA has shown promising anti-inflammatory activity.

Keywords: Anti-inflammatory drugs, Sodium valproate, Rat model.

(C) 2017 The Authors. Published by Innovare Academic Sciences Pvt Ltd. This is an open access article under the CC BY license (http://creativecommons org/licenses/by/4. 0/) DOI: http://dx.doi.org/10.22159/ajpcr.2017.v10i1.15207

\section{INTRODUCTION}

Nonsteroidal anti-inflammatory drugs (NSAIDs) that include both traditional cyclooxygenase (COX) inhibitors and the newer selective (COX-2) ones are at present the mainstay drugs for treating pain and inflammation. While at one end there is no doubt that these drugs are effective in the management of conditions such as ankylosing spondylitis, osteoarthritis, and rheumatoid arthritis, on the other hand they are known to cause adverse effects. While traditional agents are known to cause gastrointestinal adverse effects with chronic use, the COX-2 inhibitors possess a cardiotoxic potential [1]

Corticosteroids are known to possess anti-inflammatory and immune modulatory effects. Like NSAIDs, they are useful in the management of painful inflammatory conditions such as rheumatoid arthritis and gout [2]. However, they cause gastritis, proximal muscle weakness, diabetes, and they predispose to infections [3].

The quest for an ideal anti-inflammatory, which is effective and nontoxic at the same time, has got the researchers thinking. Various avenues have been explored.

A commonly used antiepileptic drug, sodium valproate has been found to be effective in many nonepileptic conditions like bipolar disorder and migraine prophylaxis, thanks to its multiple mechanisms of action [4]. One such mechanism of action is inhibition of histone deacetylation (HDAC). It is reported that valproate has neuroprotective and anti-inflammatory properties due to HDAC inhibition [5]

Omega-3 fatty acids, such as eicosapentaenoic acid and the DHA, have shown to decrease the risk of developing many diseases such as cancer, hypertension, and cardiac disease. They have been shown to compete against arachidonic acid for lipooxygenase and COX thereby preventing production of proinflammatory mediators. In addition, this being a natural product is less likely to cause adverse effects compared to the traditional anti-inflammatory drugs [6]. In view of these reports, a study was initiated with a plan to assess the effect of sodium valproate alone and in combination with DHA in rat models of inflammation.

\section{METHODS}

An in vivo experimental study conducted in the Department of Pharmacology, Kasturba Medical College, Manipal University, Manipal, Karnataka, India.

\section{Selection and animal handling}

A total of 48 adult Wistar albino healthy rats were selected for this study, which were locally bred in the Central Animal House of Manipal University, Manipal. These animals weighed 150-200 g and they were around 6 months old and were housed under controlled conditions with temperature of about $23 \pm 2{ }^{\circ} \mathrm{C}, 50 \pm 5 \%$ humidity, and $10-14 \mathrm{hr}$ of light and dark cycle, respectively. These animals were individually housed in polypropylene cages which contained paddy husk (procured locally) which was sterile, as bedding throughout the study and had easy access to animal chow (sterile food) and water ad libitum. This study was initiated after taking approval from the Institutional Animal Ethics Committee (IAEC/KMC/75/2014 dated August 22, 2014). The experiments were conducted in accordance to CPCSEA guidelines.

\section{Identification of individual animals}

Rats from each treatment group were marked using different colored marks on their tails, for easy identification and experimentation, according to the group allotted.

Drugs, reagents, and other materials

Three drugs were used during the study. Indomethacin, sodium valproate, and DHA were used. The pure powder form was used, dissolved in distilled water.

\section{Evaluation of anti-inflammatory activity}

A total of 48 adult Wistar albino male rats weighing 150-200 g were equally divided into 8 groups of six rats each. The rats were weighed and marked. Group I was taken as the control (distilled water $1 \mathrm{ml} / \mathrm{kg}$ ), 
Group II was given indomethacin injection $(10 \mathrm{mg} / \mathrm{kg})$ intraperitoneal (i.p.), Group III-V, were injected (i.p.) with sodium valproate 100, 200, and $400 \mathrm{mg} / \mathrm{kg}$ dissolved in distilled water, and Group VI-VIII were given sodium valproate 100,200 , and $400 \mathrm{mg} / \mathrm{kg}$ dissolved with distilled water along with DHA $300 \mathrm{mg} / \mathrm{kg}$ (i.p.), respectively. The dose of sodium valproate was chosen as $100 \mathrm{mg} / \mathrm{kg}, 200 \mathrm{mg} / \mathrm{kg}$, and $400 \mathrm{mg} / \mathrm{kg}$ based on a study performed by Raza et al. [7]. The dose of DHA was chosen as $300 \mathrm{mg} / \mathrm{kg}$ based on a study done by Gao et al. [8]

\section{Carrageenan-induced paw edema model}

The plethysmometer is a device used to measure small changes in volume. Two interconnected Perspex tubes form the volume transducer and these tubes are filled with conductive solution. The displacement produced as a result of object immersion in the measuring tube is measured in the second tube in between the platinum electrodes.

The albino Wistar rats were starved overnight. The test drug was administered. At 30 minutes post administration of test or reference drug, each animal received $0.1 \mathrm{ml}$ of $1 \%$ carrageenan subcutaneously in the hind paw of the right side. The left paw was then injected subcutaneously with the same volume of distilled water. Following this, the volume of the paw was measured using plethysmometer by the volume displacement technique which was sensitive to a volume change of $0.01 \mathrm{ml}$. The paw volume was measured pretreatment and post-treatment at 60 minutes gap at $60,120,180$, and 240 minutes. The difference in the paw volume was then measured and values tabulated. Percent inhibition of inflammation was then calculated using the formula:

\section{Percent inhibition=[1-(A-B/C-D) $]^{*} 100$.}

Where A and B were the mean paw volume of the rats before and after injection of carrageenan, respectively, in the test group, and C and D are the mean paw volume of rats before and after carrageenan injection, respectively, in the control group [9].

\section{Cotton pellet granuloma model}

The albino Wistar rats were weighed and marked. A sterile cotton pellet was weighed, and $30 \mathrm{mg}$ was placed in the subcutaneous plane in the groin of rats. Group I was taken as a control (distilled water $1 \mathrm{ml} / \mathrm{kg}$ ), Group II was be given an (i.p.) injection of indomethacin ( $10 \mathrm{mg} / \mathrm{kg})$, Groups III-V were injected (i.p.) with sodium valproate 100,200 , and $400 \mathrm{mg} / \mathrm{kg}$ dissolved with distilled water, and Groups VI-VIII were given sodium valproate 100,200 , and $400 \mathrm{mg} / \mathrm{kg}$ dissolved with distilled water along with DHA $300 \mathrm{mg} / \mathrm{kg}$, respectively, once daily for seven consecutive days. On day 8 , the rats were sacrificed by overdose of ketamine $(80 \mathrm{mg} / \mathrm{kg}$; i.p.) followed by cervical dislocation and cotton pellets were removed. Extraneous tissue was separated following, which the pellets were dried overnight at a temperature of $60^{\circ} \mathrm{C}$ to a constant weight. Any increase in the weight of the pellet was taken as deposition of granuloma tissue [10].

A washout period of 1-month was maintained after studying each inflammation models.

\section{Statistical analysis}

The data obtained were analyzed using IBM statistical package for social sciences version 22.0. The results were expressed as mean \pm standard error of mean. The significance of difference within the groups at different end points was assessed using repeated measures one-way analysis of variance (ANOVA). Similarly, the significance of differences between the various groups were checked for using ANOVA, followed by post hoc Tukey's test. Importantly, all test groups were compared against the control and standard groups, to arrive at a conclusion regarding the results. $P<0.05$ was considered to be statistically significant.

\section{RESULTS}

\section{Anti-inflammatory activity}

1. Carrageenan-induced paw edema model

The paw volume was significantly lower $(0.23 \pm 0.05, \mathrm{p}=0.010, \%$ inhibition

- 58.93\%) in the indomethacin $(10 \mathrm{mg} / \mathrm{kg})$ treated group, $0.11 \pm 0.03$, $\mathrm{p}<0.001, \%$ inhibition $-80.36 \%$ in sodium valproate $(100 \mathrm{mg} / \mathrm{kg})$ plus DHA (300 mg/kg) group, $0.15 \pm 0.03, \mathrm{p}=0.001, \%$ inhibition $-73.22 \%$ in the sodium valproate $(200 \mathrm{mg} / \mathrm{kg})$ plus DHA (300 mg/kg) group, and $0.16 \pm 0.04, p=0.001, \%$ inhibition $-71.43 \%$ in the sodium valproate $(400 \mathrm{mg} / \mathrm{kg}$ ) plus DHA (300 mg/kg) group at 60 minutes when compared to control (0.56 \pm 0.08$)$ as shown in Table 1 and Fig. 1 .

The paw volume was significantly lower $(0.34 \pm 0.06, p<0.001, \%$ inhibition - $68.81 \%)$ in the indomethacin $(10 \mathrm{mg} / \mathrm{kg})$ treated group, $0.53 \pm 0.26, \mathrm{p}=0.015$, \% inhibition - $51.38 \%$ in sodium valproate (200 mg/kg) group, $0.46 \pm 0.13, \mathrm{p}=0.005$, \% inhibition - $57.80 \%$ in sodium valproate ( $400 \mathrm{mg} / \mathrm{kg}$ ) group, $0.31 \pm 0.06, \mathrm{p}<0.001, \%$ inhibition - $71.56 \%$ in sodium valproate $(100 \mathrm{mg} / \mathrm{kg})$ plus DHA (300 mg $/ \mathrm{kg}$ ) group, $0.32 \pm 0.06$, p $<0.001$, \% inhibition $-70.65 \%$ in the sodium valproate $(200 \mathrm{mg} / \mathrm{kg}$ ) plus DHA (300 mg/kg) group, and $0.25 \pm 0.05, \mathrm{p}<0.001, \%$ inhibition $-77.07 \%$ in the sodium valproate (400 mg/kg) plus DHA (300 mg/kg) group at 120 minutes when compared to control (1.09 \pm 0.16$)$ as shown in Table 1 and Fig. 1.

The paw volume was significantly lower $(0.39 \pm 0.06, \mathrm{p}<0.001, \%$ inhibition - 73.65\%) in the indomethacin (10 mg/kg) treated group, $0.93 \pm 0.1, \mathrm{p}=0.001, \%$ inhibition $-37.17 \%$ in sodium valproate (100 mg/kg) group, $0.63 \pm 0.16, \mathrm{p}<0.001$, \% inhibition - $57.44 \%$ in sodium valproate (200 mg/kg) group, $0.31 \pm 0.06, \mathrm{p}<0.001, \%$ inhibition - $79.06 \%$ in sodium valproate $(400 \mathrm{mg} / \mathrm{kg}$ ) group, $0.38 \pm 0.06$, $\mathrm{p}<0.001, \%$ inhibition $-74.33 \%$ in sodium valproate $(100 \mathrm{mg} / \mathrm{kg})$ plus DHA $(300 \mathrm{mg} / \mathrm{kg}$ ) group, $0.40 \pm 0.07$, p $<0.001$, $\%$ inhibition $-72.98 \%$ in the sodium valproate $(200 \mathrm{mg} / \mathrm{kg})$ plus DHA $(300 \mathrm{mg} / \mathrm{kg})$ group, and $0.34 \pm 0.06, \mathrm{p}<0.001, \%$ inhibition $-77.03 \%$ in the sodium valproate (400 mg/kg) plus DHA (300 mg/kg) group at 180 minutes when compared to control (1.48 \pm 0.06$)$ as shown in Table 1 and Fig. 1 .

The paw volume was significantly lower $(0.41 \pm 0.04, \mathrm{p}<0.001, \%$ inhibition $-72.85 \%)$ in the indomethacin $(10 \mathrm{mg} / \mathrm{kg})$ treated group, $0.89 \pm 0.28, \mathrm{p}=0.037, \%$ inhibition $-41.06 \%$ in sodium valproate (100 mg $/ \mathrm{kg}$ ) group, $0.29 \pm 0.03, \mathrm{p}<0.001$, \% inhibition - $80.80 \%$ in sodium valproate $(400 \mathrm{mg} / \mathrm{kg}$ ) group, $0.57 \pm 0.06, \mathrm{p}<0.001, \%$

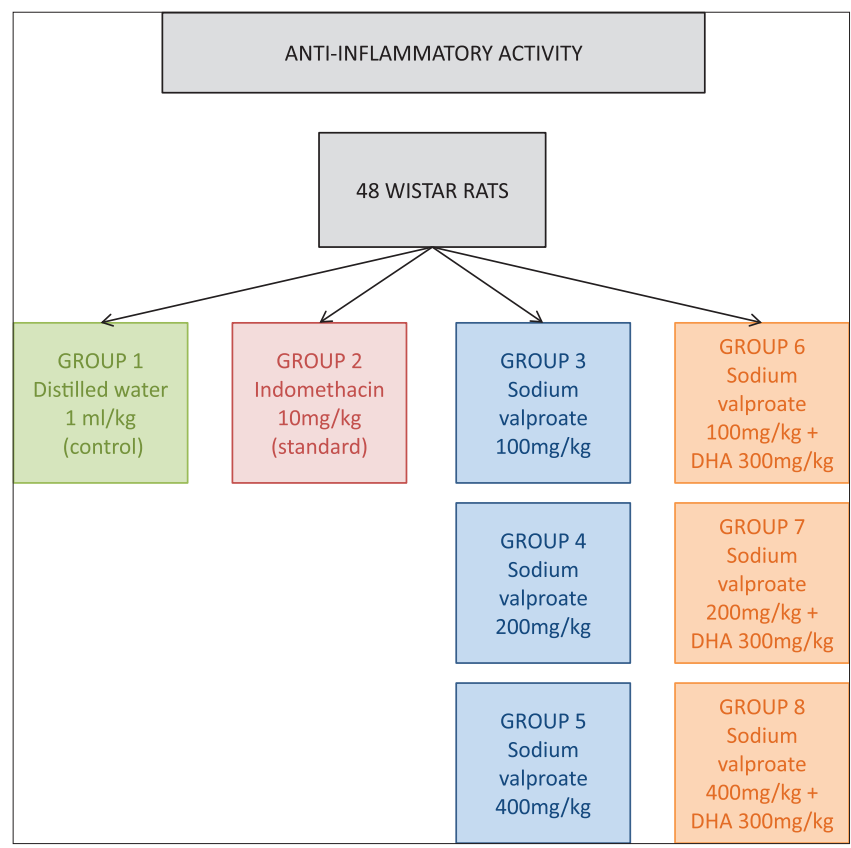

Fig. 1: Anti-inflammatory activity of sodium valproate and docosahexaenoic acid in carrageenan-induced paw edema model, mean difference in paw volume $(\mathrm{mL}) \pm$ Standard error of mean at different time points. $b$ denotes $p<0.05$ compared to control $p$ value obtained by one-way analysis of variance followed by post hoc Tukey's test 
Table 1: Carrageenan-induced paw edema model

\begin{tabular}{|c|c|c|c|c|}
\hline \multirow[t]{2}{*}{ Group } & \multicolumn{4}{|c|}{ Mean difference in paw volume $(\mathrm{ml}.) \pm S E M$ at different time points (percentage inhibition of edema) } \\
\hline & 60 minutes & 120 minutes & 180 minutes & 240 minutes \\
\hline Control & $0.56 \pm 0.08(0)$ & $1.09 \pm 0.16(0)$ & $1.48 \pm 0.06(0)$ & $1.51 \pm 0.06(0)$ \\
\hline Indomethacin $10 \mathrm{mg} / \mathrm{kg}$ (std) & $0.23 \pm 0.05^{\mathrm{b}}(58.93)$ & $0.34 \pm 0.06^{b}(68.81)$ & $0.39 \pm 0.06^{\mathrm{b}}(73.65)$ & $0.41 \pm 0.04^{\mathrm{b}}(72.85)$ \\
\hline Val $100 \mathrm{mg} / \mathrm{kg}$ & $0.53 \pm 0.11(5.36)$ & $0.78 \pm 0.10(28.45)$ & $0.93 \pm 0.11^{\mathrm{b}}(37.17)$ & $0.89 \pm 0.28^{\mathrm{b}}(41.06)$ \\
\hline Val $200 \mathrm{mg} / \mathrm{kg}$ & $0.31 \pm 0.03(44.65)$ & $0.53 \pm 0.26^{\mathrm{b}}(51.38)$ & $0.63 \pm 0.16^{\mathrm{b}}(57.44)$ & $0.98 \pm 0.18(35.10)$ \\
\hline Val $400 \mathrm{mg} / \mathrm{kg}$ & $0.32 \pm 0.05(42.86)$ & $0.46 \pm 0.13^{\mathrm{b}}(57.80)$ & $0.31 \pm 0.06^{\mathrm{b}}(79.06)$ & $0.29 \pm 0.03^{\mathrm{b}}(80.80)$ \\
\hline Val $100 \mathrm{mg} / \mathrm{kg}+\mathrm{DHA} 300 \mathrm{mg} / \mathrm{kg}$ & $0.11 \pm 0.03^{\mathrm{b}}(80.36)$ & $0.31 \pm 0.06^{b}(71.56)$ & $0.38 \pm 0.06^{\mathrm{b}}(74.33)$ & $0.57 \pm 0.06^{\mathrm{b}}(62.26)$ \\
\hline Val $200 \mathrm{mg} / \mathrm{kg}+\mathrm{DHA} 300 \mathrm{mg} / \mathrm{kg}$ & $0.15 \pm 0.03^{\mathrm{b}}(73.22)$ & $0.32 \pm 0.06^{\mathrm{b}}(70.65)$ & $0.40 \pm 0.07^{\mathrm{b}}(72.98)$ & $0.45 \pm 0.11^{\mathrm{b}}(70.20)$ \\
\hline Val $400 \mathrm{mg} / \mathrm{kg}+\mathrm{DHA} 300 \mathrm{mg} / \mathrm{kg}$ & $0.16 \pm 0.04^{\mathrm{b}}(71.43)$ & $0.25 \pm 0.05^{\mathrm{b}}(77.07)$ & $0.34 \pm 0.06^{\mathrm{b}}(77.03)$ & $0.35 \pm 0.05^{\mathrm{b}}(76.83)$ \\
\hline
\end{tabular}

All values are expressed as Mean \pm SEM. ${ }^{b} \mathrm{p}<0.05$ compared to control. $\mathrm{p}$ value obtained by one-way ANOVA followed by post hoc Tukey's test. SEM: Standard error of mean

inhibition - $62.26 \%$ in sodium valproate $(100 \mathrm{mg} / \mathrm{kg})$ plus DHA (300 mg/kg) group, $0.45 \pm 0.11, \mathrm{p}<0.001$, \% inhibition $-70.20 \%$ in the sodium valproate (200 mg/kg) plus DHA (300 mg/kg) group, and $0.35 \pm 0.05, \mathrm{p}<0.001, \%$ inhibition $-76.83 \%$ in the sodium valproate (400 mg/kg) plus DHA (300 mg/kg) group at 240 minutes when compared to control $(1.51 \pm 0.06)$ as shown in Table 1 and Fig. 1.

\section{Cotton pellet granuloma}

As shown in Table 2 and Fig. 2, the dry weight of cotton pellet granuloma in control group was $0.13 \pm 0.01 \mathrm{~g}$, in indomethacin $(10 \mathrm{mg} / \mathrm{kg})$ group was $0.03 \pm 0.00 \mathrm{~g}(\mathrm{p}<0.001)$, in sodium valproate $(100 \mathrm{mg} / \mathrm{kg})$ group was $0.13 \pm 0.01 \mathrm{~g}(\mathrm{p}=1.000)$, in sodium valproate $(200 \mathrm{mg} / \mathrm{kg})$ group was $0.13 \pm 0.01 \mathrm{~g}(\mathrm{p}=1.000)$, in sodium valproate $(400 \mathrm{mg} / \mathrm{kg})$ group was $0.07 \pm 0.02 \mathrm{~g}(\mathrm{p}<0.001)$, in sodium valproate $(100 \mathrm{mg} / \mathrm{kg})$ plus DHA (300 mg $/ \mathrm{kg}$ ) group was $0.08 \pm 0.03 \mathrm{~g}(\mathrm{p}=0.001)$, sodium valproate (200 mg/kg) plus DHA (300 mg/kg) group was $0.06 \pm 0.03 \mathrm{~g}(\mathrm{p}<0.001)$, and sodium valproate $(400 \mathrm{mg} / \mathrm{kg}$ ) plus DHA (300 mg/kg) group was $0.07 \pm 0.02 \mathrm{~g}(\mathrm{p}<0.001)$. The drug sodium valproate when given alone in low doses (100 and $200 \mathrm{mg} / \mathrm{kg}$ ) did not show any statistically significant anti-inflammatory property when compared to control. However, $400 \mathrm{mg} / \mathrm{kg}$ of sodium valproate when given alone showed statistically significant anti-inflammatory activity when compared to control. All the three groups where sodium valproate was combined with DHA showed statistically significant anti-inflammatory activity as compared to control. However, the reduction in granuloma formation in these groups was less than that of standard drug indomethacin.

\section{DISCUSSION}

The anti-inflammatory action of sodium valproate along with DHA was assessed using cotton pellet granuloma as well as paw edema model induced by Irritant carrageenan which are standard models for screening agents for anti-inflammatory activity. Paw edema model with carrageenan in rats is the standard model to evaluate acute inflammation. Carrageenan is the irritant that is preferred for testing drugs for anti-inflammatory activity as it is nonantigenic and also due to the absence of systemic effects. It induces edema in two phases; the first phase is characterized by serotonin release and also the release of kinins and histamine, whereas the second phase is due to the release of prostaglandins and slow reacting substances.

In the carrageenan induced paw edema model, a combination of sodium valproate all three doses used with $300 \mathrm{mg}$ of DHA showed anti-inflammatory activity compared to control at 60 minutes. Sodium valproate $200 \mathrm{mg}$, sodium valproate $400 \mathrm{mg}$, combination of sodium valproate $100 \mathrm{mg}$ with $300 \mathrm{mg}$ of DHA, combination of sodium valproate $200 \mathrm{mg}$ with $300 \mathrm{mg}$ of DHA, and combination of sodium valproate $400 \mathrm{mg}$ with $300 \mathrm{mg}$ of DHA showed anti-inflammatory activity compared to control at 120 minutes. Sodium valproate $100 \mathrm{mg}$, sodium valproate $200 \mathrm{mg}$, sodium valproate $400 \mathrm{mg}$, combination of sodium valproate $100 \mathrm{mg}$ with $300 \mathrm{mg}$ of DHA, combination of sodium valproate $200 \mathrm{mg}$ with $300 \mathrm{mg}$ of DHA, and combination of sodium valproate $400 \mathrm{mg}$ with $300 \mathrm{mg}$ of DHA showed anti-inflammatory activity compared to control at 180 and 240 minutes. The similar
Table 2: Cotton pellet granuloma model

\begin{tabular}{lc}
\hline Groups & $\begin{array}{c}\text { Mean dry weight of } \\
\text { granuloma (mg) }\end{array}$ \\
\hline Control & $0.13 \pm 0.01$ \\
Indomethacin $10 \mathrm{mg} / \mathrm{kg}$ (std) & $0.03 \pm 0.00^{\mathrm{b}}$ \\
Val $100 \mathrm{mg} / \mathrm{kg}$ & $0.13 \pm 0.01^{\mathrm{c}}$ \\
Val $200 \mathrm{mg} / \mathrm{kg}$ & $0.13 \pm 0.01^{\mathrm{c}}$ \\
Val $400 \mathrm{mg} / \mathrm{kg}$ & $0.07 \pm 0.02^{\mathrm{b}}$ \\
Val $100 \mathrm{mg} / \mathrm{kg}+\mathrm{DHA} 300 \mathrm{mg} / \mathrm{kg}$ & $0.08 \pm 0.03^{\mathrm{bc}}$ \\
Val $200 \mathrm{mg} / \mathrm{kg}+\mathrm{DHA} 300 \mathrm{mg} / \mathrm{kg}$ & $0.06 \pm 0.03^{\mathrm{b}}$ \\
Val $400 \mathrm{mg} / \mathrm{kg}+\mathrm{DHA} 300 \mathrm{mg} / \mathrm{kg}$ & $0.07 \pm 0.02^{\mathrm{bc}}$ \\
\hline
\end{tabular}

All values are expressed as Mean \pm SEM. ${ }^{\mathrm{b}} \mathrm{p}<0.05$ compared to control and ${ }^{c} \mathrm{p}<0.05$ compared to standard. $p$ value obtained by one-way ANOVA followed by post hoc Tukey's test. SEM: Standard error of mean, DHA: Docosahexaenoic acid

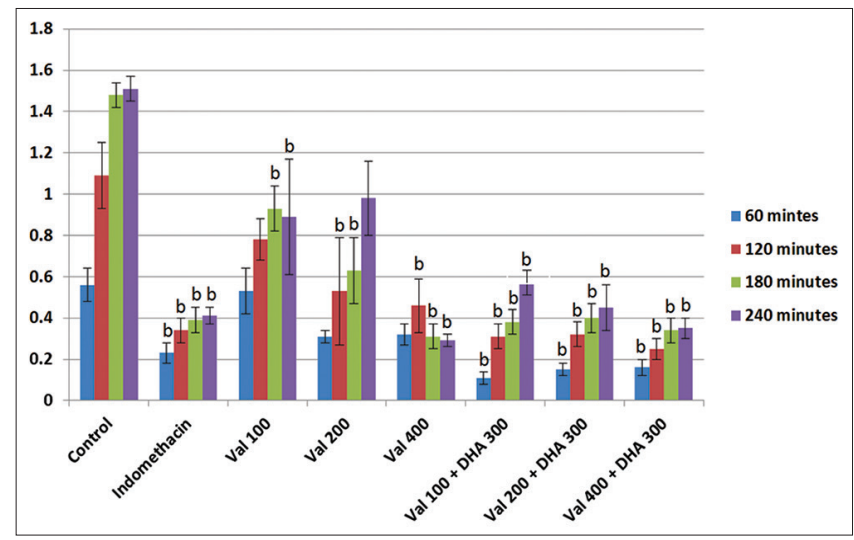

Fig. 2: Anti-inflammatory activity of sodium valproate and docosahexaenoic acid on cotton pellet granuloma model, mean dry weight of granuloma ( $\mathrm{mg}$ ). $\mathrm{b}$ denotes $\mathbf{p}<\mathbf{0 . 0 5}$ compared to control and $c$ denotes $p<0.05$ compared to standard $p$ value obtained by one-way analysis of variance followed by post hoc Tukey's test

anti-inflammatory activity of sodium valproate was reported by earlier workers [7].

In the cotton pellet granuloma model, sodium valproate given alone at $400 \mathrm{mg}$, combination of sodium valproate $100 \mathrm{mg}$ with $300 \mathrm{mg}$ of DHA, combination of sodium valproate $200 \mathrm{mg}$ with $300 \mathrm{mg}$ of DHA, and combination of sodium valproate $400 \mathrm{mg}$ with $300 \mathrm{mg}$ of DHA showed anti-inflammatory activity as compared to control. However, the antiinflammatory activity was less than that of standard drug indomethacin.

The carrageenan injection into the paw of the rat is said to raise the levels of interleukin 6 (IL-6), IL-1 $\beta$, tumor necrosis factor alpha (TNF $\alpha$ ), and cytokine-induced neutrophil chemoattractant 1 levels [11]. In addition, nitric oxide is also involved in the carrageenan-induced inflammation. Sodium valproate, an HDACI inhibits the cytokines like 
IL- 6 and TNF $\alpha$. Migration of leukocytes to the inflammatory site is also inhibited [12]. Sodium valproate is also an antioxidant and inhibits the production of reactive oxygen species [13]. These effects of sodium may be responsible for its anti-inflammatory activity.

Studies were done by Ferrucci et al. have shown that there exists a reciprocal connection in between the omega- 3 fatty acids levels and the inflammatory cytokines like TNF $\alpha$ and IL-6 and C-reactive protein [14] Another study was done by Rao et al. in omega- 3 fatty acid deficient rats has shown up-regulation of enzyme which converts arachidonic acid to prostaglandin E2 in these rats [15]. A study was done by McNamara et al. have shown that deficiency of omega- 3 fatty acids increases the central serotonin turnover [16].

DHA suppresses nuclear factor Kappa Beta mediated nuclear translocation thereby inhibiting cytokine $(\mathrm{TNF} \alpha$, vascular endothelial growth factor, and IL-1 $\beta$ ) mediated adhesion molecule expression [17]. DHA is also a peroxisome proliferator activated receptor gamma activator. In addition, they produce resolvins and protectins through pathways involving lipoxygenase and COX enzymes, which have an anti-inflammatory role. These protectins and resolvins prevent the neutrophilic infiltration by preventing transendothelial migration [18]. All these effects probably contribute to the anti-inflammatory effects.

In conclusion, the combination of sodium valproate and DHA has shown better anti-inflammatory activity. A well planned clinical trial using this combination may be worthwhile to evaluate the possibility its therapeutic use in various inflammatory conditions.

\section{CONCLUSION}

Higher doses of sodium valproate, either used alone or along with DHA showed statistically significant anti-inflammatory activity in both the models of inflammation. The combination of sodium valproate and DHA has shown promising anti-inflammatory activity and was almost comparable to standard drugs used in this study. Clinical studies on this combination may be worthwhile.

\section{REFERENCES}

1. Alam N, Kumar R, Bhardwaj A, Pharmacovigilance for adverse drug reactions in patients on non-steroidal anti-inflammatory drugs and hepatic dysfunctions in aceclofenac therapy in south Delhi hospital. Int J Pharm Pharm Sci 2012;4(5):128-31.

2. Sibilia J. Corticosteroids and inflammation. Rev Prat 2003;53(5):495-501.

3. Walsh LJ, Wong CA, Oborne J, Cooper S, Lewis SA, Pringle M, et al. Adverse effects of oral corticosteroids in relation to dose in patients with lung disease. Thorax 2001;56(4):279-84.

4. DeVane CL. Pharmacokinetics, drug interactions, and tolerability of valproate. Psychopharmacol Bull 2003;37 Suppl 2:25-42.

5. Kim HJ, Rowe M, Ren M, Hong JS, Chen PS, Chuang DM. Histone deacetylase inhibitors exhibit anti-inflammatory and neuroprotective effects in a rat permanent ischemic model of stroke: Multiple mechanisms of action. J Pharmacol Exp Ther 2007;321(3):892-901.

6. Hussein JS, El-Khayat Z, Morsy S, Oraby F, Singer G. The effect of fish oil on oxidant/antioxidant status in diabetic rats through the reduction of arachidonic acid in the cell membrane. Int $\mathrm{J}$ Pharm Pharm Sc 2014;6(2):196-9.

7. Raza M, Dhariwal MA, Ageel AM, Qureshi S. Evaluation of the antiinflammatory activity of sodium valproate in rats and mice. Gen Pharmacol 1996;27(8):1395-400.

8. Gao J, Wang X, Sun H, Cao Y, Liang S, Wang H, et al. Neuroprotective effects of docosahexaenoic acid on hippocampal cell death and learning and memory impairments in a valproic acid-induced rat autism model. Int J Dev Neurosci 2016;49:67-78.

9. Winter CA, Risley EA, Nuss GW. Carrageenin-induced edema in hind paw of the rat as an assay for antiiflammatory drugs. Proc Soc Exp Biol Med 1962;111:544-7.

10. Goldstein S, Shemano I, Demeo R, Beiler JM. Anti-inflammatory activity of several irritants in three models of experimental inflammation in rats. Arch Int Pharmacodyn Ther 1967;167(1):39-53.

11. Loram LC, Fuller A, Fick LG, Cartmell T, Poole S, Mitchell D. Cytokine profiles during carrageenan-induced inflammatory hyperalgesia in rat muscle and hind paw. J Pain 2007;8(2):127-36.

12. Ximenes JC, de Oliveira Gonçalves D, Siqueira RM, Neves KR, Santos Cerqueira G, Correia AO, et al. Valproic acid: An anticonvulsant drug with potent antinociceptive and anti-inflammatory properties. Naunyn Schmiedebergs Arch Pharmacol 2013;386(7):575-87.

13. Shang Y, Jiang YX, Ding ZJ, Shen AL, Xu SP, Yuan SY, et al. Valproic acid attenuates the multiple-organ dysfunction in a rat model of septic shock. Chin Med J (Engl) 2010;123(19):2682-7.

14. Ferrucci L, Cherubini A, Bandinelli S, Bartali B, Corsi A, Lauretani F, et al. Relationship of plasma polyunsaturated fatty acids to circulating inflammatory markers. J Clin Endocrinol Metab 2006;91:439-46.

15. Rao JS, Ertley RN, DeMar JC Jr, Rapoport SI, Bazinet RP, Lee HJ. Dietary n-3 PUFA deprivation alters expression of enzymes of the arachidonic and docosahexaenoic acid cascades in rat frontal cortex. Mol Psychiatry 2007;12(2):151-7.

16. McNamara RK, Jandacek R, Rider T, Tso P, Cole-Strauss A, Lipton JW. Omega-3 fatty acid deficiency increases constitutive pro-inflammatory cytokine production in rats: Relationship with central serotonin turnover. Prostaglandins Leukot Essent Fatty Acids 2010;83(4-6):185-91.

17. Chen W, Esselman WJ, Jump DB, Busik JV. Anti-inflammatory effect of docosahexaenoic acid on cytokine-induced adhesion molecule expression in human retinal vascular endothelial cells. Invest Ophthalmol Vis Sci 2005;46(11):4342-7.

18. Calder PC. Omega-3 fatty acids and inflammatory processes. Nutrients 2010;2(3):355-74. 